\title{
Determinants of Job Satisfaction in Higher Education Sector: Empirical Insights from Malaysia
}

\author{
Jalal Hanaysha \\ Senior Lecturer, Faculty of Business and Management, \\ DRB-HICOM University of Automotive Malaysia, 26607, Pekan, Pahang, Malaysia \\ E-mail: jalal.hanayshi@yahoo.com
}

Received: February 02, 2016 Accepted: February 29, 2016 Published: March 17, 2016

doi:10.5296/ijhrs.v6i1.9199 URL: http://dx.doi.org/10.5296/ijhrs.v6i1.9199

\begin{abstract}
Job satisfaction is one of the most important topics in the field of management and it has received a noteworthy attention from both scholars as well as business practitioners. This is because employee job satisfaction is the main predictor of organizational success and long term performance. This paper examines the impact of four factors namely employee engagement, employee motivation, work environment, and organizational learning on job satisfaction in higher education sector. The data were collected using a survey instrument from 242 employees of public universities in northern area of Malaysia. The collected data was analysed using SPSS and structural equation modelling. Overall, the findings indicated that employee engagement has significant positive effect on job satisfaction. It was also found that employee motivation has significant positive effect on job satisfaction. Moreover, this study revealed that work environment and organizational learning have significant positive effects on job satisfaction. These results provide useful insights for the management in higher educational institutions and suggest that the selected human resource factors are very important for improving job satisfaction.
\end{abstract}

Keywords: Job satisfaction, employee motivation, organizational learning, work engagement, work environment 


\section{Introduction}

Job satisfaction is an important research topic that captured the attention of many scholars in organization and management disciplines (Luthans, 2005). The high attentions toward studying job satisfaction clearly show the importance of this topic. In order for any organization to be truly successful, it is vital to ensure that its employees are satisfied with their jobs and working environment. Certain scholars illustrated that organizations which successfully manage to satisfy their employees are likely to have high performance (Moradi, Almutairi, Idrus, \& Emami, 2011; Robbins, 2003). Furthermore, satisfied employees are in most cases likely to be productive and highly committed. As the performance of any organization largely depends on its employees or workforce, therefore, it is necessary to ensure that they have the good skills to meet business needs. According to Arnold and Silvester (2005), organizations should emphasize on job satisfaction among their employees to maintain long term performance.

Jolodar and Jolodar (2012) demonstrated that job satisfaction is directly linked with human resources development and employee productivity. As a result, higher levels of job satisfaction will boost productivity and ultimately organizational elevation. Based on the literature review, it shows there are several factors that could affect job satisfaction and make employees happier with their jobs (Lo \& Ramayah, 2011). One of these factors is organizational learning which emphasizes on the importance of the contributing factors for better learning about one's work (Chiva, Alegre, \& Lapiedra, 2007). Organizational learning can also be described as the ability of an organization to implement the relevant management practices, techniques, and structures that facilitate and encourage employee learning (Goh \& Richards, 1997). Organizational learning represents the capability of an organization in expanding the knowledge and skills of its employees to ensure better productivity and excellence at workplace.

Employee engagement is another factor that can influence job satisfaction. The concept of employee engagement has appeared fairly in the recent literature. Kahn (1990) referred work engagement to "the harnessing of organization members" selves to their work roles; in engagement, people employ and express themselves physically, cognitively and emotionally during role performances" (p. 694). Nowack (2011) reported that work engagement plays an important role in affecting job satisfaction and employee retention. However, previous research reveals that there is a little information about the association between employee engagement and job satisfaction (Buckingham \& Coffman, 1999). By exploring the link between both variables, it will enrich the understandings about the topic and provide useful suggestions for policy makers to set up the right strategies.

Furthermore, certain scholars ascertained that job satisfaction can be affected by work environment (Bakotić, \& Babić, 2013; Jain \& Kaur, 2014) and employee motivation (Maharjan, 2012; Naufal, Suryaputra, \& Sondakh, 2012; Saleem, Mahmood, and Mahmood, 2010). According to Jain and Kuar (2014), comfortable work environment increases the happiness of employees with their jobs, and this ultimately leads to the growth of an organisation and economy. Sohail, Saleem, Ansar, and Azeem (2014) also demonstrated that 
motivated and committed employees tend to perform well and feel more satisfied with their jobs as compared to those who are not. Therefore, organizations should be aware about the changes in business environment and frequently upgrade the necessary facilities for employees to ensure they can perform their tasks with full energy and satisfaction. For example, a pleasant working environment and motivation can inspire employees to be more productive and develop higher levels of satisfaction among them.

This study aims to examine the effects of employee engagement, employee motivation, work environment, and organizational learning on job satisfaction at public universities in northern area of Malaysia. Based on the literature review, it is observed that there are limited research works which have come across examining the link between the stated factors, particularly, in public sector. According to Hsu (2009), there are few studies that tested the effect of organizational learning on job satisfaction. Considering the gaps mentioned above, this study aims to provide a significant contribution to the existing literature by examining the links between the stated variables. The next section presents a brief review of literature and highlights the related studies on the aforementioned variables.

\section{Literature Review}

\subsection{Job Satisfaction}

Job satisfaction is one of the key factors that affect organizational success and performance. Job satisfaction can be viewed as a general evaluation of "an employee's attitudes of overall acceptance, contentment, and enjoyment in his or her work" (Lee-Kelley et al., 2007, p. 206). Cranny et al. (1992) referred job satisfaction to the employee's emotional responses to a job based on comparing the desired outcomes with perceived ones. According to Roodt, Rieger, and Sempane (2002), job satisfaction can be described according to an employee's own evaluation of his/ her job as a result of work experience. On the other hand, Arnold and Feldman (1986, p.86) defined job satisfaction as "the amount of overall affect that individuals have toward their job". This means that a higher level of job satisfaction indicates that an employee likes his or her job, appreciates it, and has positive feeling about it. In general, it can be said that job satisfaction reflects the overall evaluation of an employee toward his or her job by comparing the expectations with what is perceived.

Job satisfaction has been considered as a top priority for several organizations and it can be evaluated based on several elements. High job satisfaction can be felt through the comfort and positive experience that an employee relates to his job. According to Bakotić and Babić (2013), job satisfaction encompasses several factors such as nature of job, salary, work stress, working environment, colleagues, supervisors, and working hours. On the other hand, Pitaloka and Sofia (2014) established that job satisfaction can be measured according to the following criteria: the job itself, rewards or benefits, relationship quality with the employees, and promotional opportunities. Further explanation toward the measures of job satisfaction was presented by Spector (1997) who suggested nine elements: pay, job promotion, supervision, fringe benefits, contingent rewards, working conditions, co-workers, nature of the job, and communication. But, Peretomode (1991) suggested that job satisfaction is directly associated with job status. In other words, employees with higher the job status are 
likely to have higher levels of job satisfaction.

In the current business scenario, managers nowadays feel morally responsible for developing higher levels of job satisfaction among their employees, most importantly due to its influence on productivity, absenteeism, turnover, and on union activities (Arnold \& Feldman, 1986). Moreover, organisations are aware that having employees who feel satisfied about their works can contribute enormously towards organisational effectiveness and eventual existence. Spector (2003) illustrated that job satisfaction is related to significant employee and organisational outcomes, ranging from job performance to health and longevity. Overall, job satisfaction provides several benefits for both employees as well to the organization. From the perspective of employees, job satisfaction leads to the happiness and comfort at workplace and indicates that employees enjoy what they do. From organizational perspective, job satisfaction leads to favourable outcomes such as performance and low percentage of employee turnover. Besides that, satisfied employees tend to be more creative and can support the management in decision making.

\subsection{Employee Engagement}

Employee engagement has been a top business priority for many organizations. A number of scholars (Buckingham \& Coffman, 1999; Harter, Schmidt, \& Hayes, 2002) described engaged employees as those who are involved and feel enthusiastic in their works in which they develop higher degree of satisfaction. As stated by McEwen (2011), work engagement comes from the perceptions and evaluations of employees toward their working experience, in terms of their employer, organizational management, working conditions, and the job itself. Echols (2005) declared that in order to increase employee engagement, business managers have to give significant attention to the skills, knowledge, and talents of their employees. The author further explained that when employees have the awareness about their strengths and capabilities, their levels of engagement tend to be higher, and this as a result would leads to increased performance. Moreover, Storm and Rothmann (2003) demonstrated that work engagement can be reflected through the energy, behavioural satisfaction, self-efficacy and involvement in the job.

Various definitions of work engagement exist in the previous literature. For instance, Fleming and Asplund (2007, p. 2) referred work engagement to "the ability to capture the heads, hearts, and souls of your employees to instil an intrinsic desire and passion for excellence". On the other hand, Kahn (1990) expressed work engagement as "the harnessing of organization members' selves to their work duties; because engaged personnel express themselves physically, emotionally, and cognitively during role performances" (p.694). Certain scholars regarded employee engagement as a construct that consists of cognitive, emotional, and behavioural elements that are associated with the role of employee productivity (Shuck, Rocco \& Albornoz, 2011). In other words, employee engagement reflects the commitment and attachment of an employee towards his work in an attempt to increase organizational productivity (Sundaray, 2011). Bakker and Demerouti (2008) thought about employee engagement as a positive fulfilment of work-related tasks and is characterized by vigour, dedication, and absorption. 
Previous studies found that employee engagement had a significant positive impact on job satisfaction (Imam \& Shafique, 2014; Kamalanabhan, Prakash Sai, \& Mayuri, 2009; Nowack, 2011). According to Kamalanabhan et al. (2009), engaged employees will stay with their organizations longer, and continually find smarter, more effective ways to add value for them. Sanford (2003) reported that disengaged employees cost their businesses financially via decreased profits, decreased sales, lower customer satisfaction, and lower productivity. This means that employees who are engaged in their works tend to exhibit higher satisfaction. This might be because being engaged entails higher productivity at workplace that ultimately could lead to satisfying behaviour based on the achievements. Based on the above discussion, the following hypothesis is postulated:

H1: Employee engagement has positive effect on job satisfaction.

\subsection{Employee Motivation}

Employee motivation is one of the key topics in management and it has received significant research attentions from a number of scholars in various disciplines. Luthans and Sommers (2005) thought about motivation as the process which energizes, improves attitudes and maintains good behavior and performance. Maduka and Okafor (2014) expressed motivation as the inner desire of an employee to direct his/ her behaviour towards accomplishing certain goals. In other words, motivation can be conceptualized as an employee's feeling of stimulation and interest to accomplish his/ her work or tasks efficiently. Similarly, Robbins (2001) referred motivation to the drives that can energize, guide, sustain or improve the potential of employees to do certain tasks. From the above definitions, it can be said that motivation reflects to the willingness of an employee to put his maximum energy to accomplish a particular goal with an expectation to receive a reward based on the given efforts and achievements.

As defined by Shanks (2007), motivation is the process of giving a motive that influences a person to respond to take some actions. Motivation will enable people to gain the desire to do something. Consequently, with the existence of motivation, people will be encouraged to have high spirit and force themselves to do what is required from them (Naufal et al., 2012). Saleem et al. (2010) established that motivation encourages people internally towards taking actions to accomplish a preferred task effectively in a way that can inspire them to do their works and stay commitment to their jobs. As demonstrated by Altindis (2011), work motivation is gained based on the rewards that are either intrinsic or extrinsic. The intrinsic rewards come from within the employee and can be felt after receiving the rewards, whereas extrinsic rewards come from the support of management, organizational members, and working condition.

A number of studies indicated that employee motivation has significant positive effect on job satisfaction (Hussain, Usman, Sarmad, \& Haq, 2012; Khalid, Salim, \& Loke, 2011; Maharjan, 2012; Sohail et al., 2014). Their research outcomes indicated that employees who feel motivated to do their work tend to exhibit higher levels of satisfaction and commitment as compared to those who have less motivation. Motivation is therefore very important to ensure that employees are satisfied with their jobs and can perform well as expected. Based on the 
above discussion, the following hypothesis is proposed:

H2: Employee motivation has positive effect on job satisfaction.

\subsection{Organizational Learning}

In today's business environment, several organizations are experiencing noticeable developments due to the changes in world markets which are characterized by globalisation, technological advancement, workforce diversity, and knowledge maintenance. One of the effective ways to adapt to such changes is the emphasis on organizational learning as a key component of organization culture (Razali, Amira, \& Shobri, 2013). In the fields of organizational behaviour and leadership, the concept of organizational learning has received high attentions. According to Senge (1990), a learning organization is one that encourages its employees through different programs to continually widen their capabilities to accomplish the desired outcomes through nurturing critical thinking, collective aspiration, and teamwork. The main purpose of organizational learning is to ensure valuable exchanges of knowledge that could lead to innovation, improve performance, and sustain competitive advantage (Lopez, Peon \& Ordas, 2005). Therefore, organizational learning plays an important role in enhancing organizational performance and long-term competitiveness.

Several definitions of organizational learning exist in the literature. Certain scholars (Choe, 2004; Chonko, Dubinsky, Jones, \& Roberts, 2003) regarded organizational learning as a dynamic process of building, acquiring and integrating the necessary knowledge aimed at developing resources and capabilities that contribute to improved performance (Chonko et al., 2003; Choe, 2004). Moreover, Lopez et al. (2005) defined organizational learning as "a dynamic process of creation, acquisition and integration of knowledge aimed at the development of resources and capabilities that contribute to better organizational performance" (p. 228). According to Marquardt (1996), organizational learning emphasizes on the techniques and proficiencies of knowledge transfer. Therefore, a learning organization can be expressed in terms of the key principles, characteristics, and systems of an organization that focus on collective learning (Emami, Moradi, Idrus, \& Almutairi, 2012).

Previous researches reported that organizational learning is associated with job satisfaction (Egan, Yang, \& Bartlett, 2004; Emami et al., 2012; Jolodar \& Jolodar, 2012; Moradi et al., 2011; Razali et al., 2013). Chang and Lee (2007) revealed that the promotion of organizational learning can increase job satisfaction. That is, the continuous encouragement of learning and emphasis on learning culture can change the attitude and opinions of employees' toward their jobs and improve their internal satisfaction. Yang, Lim, and McLean (2003) also considered organizational learning as one of the key predictors to job satisfaction. This means that organizations which emphasize on learning, education, and development of their employees are likely to have higher profitability and improved level of job satisfaction among their employees (Leslie, Aring, \& Brand, 1998). Rowden and Conine (2005) further declared that job satisfaction can be largely affected by the availability of job learning opportunities in the organization. Based on the above discussion, the following hypothesis is presented: 
H3: Organizational learning has positive effect on job satisfaction.

\subsection{Work Environment}

As business competition has increased and market environment is becoming dynamic and highly challenging, several organizations have realized that in order to maintain their business continuity, they have to warrant conducive and friendly working conditions for their employees (Raziq \& Maulabakhsh, 2015). Due to the availability of different choices for employees to select as a working place, they turned to emphasize on a number of elements in the working environment such as working hours, job safety and security, relation with the co-worker, esteem needs, and management support (Raziq \& Maulabakhsh, 2015). According to Jain and Kaur (2014), work environment can be defined as the environment in which employees are working. The authors incorporated several elements to evaluate the working environment such as: physical scenery (e.g. noise, equipment, and heat), basics of the job itself (e.g workload, task, and complexity), extensive business features (e.g. culture, history), and also extra business background (e.g. industry setting, employees' relation).

Previous literature indicated that working environment can be evaluated in terms of different factors. For instance, Spector (1997) revealed that working environment can be assessed according to the safety of employees, job security, respectable relations with co-workers, recognition for good achievement, motivation for a job well done, and involvement in the decision making process of the organization. Moreover, different factors in the working environment such as salaries, autonomy provided to employees, working hours, organizational structure, and communication between employees and the management can determine job satisfaction (Lane, Esser, Holte, \& Anne, 2010). According to Pitaloka and Sofia (2014), there are five factors that employee tend to consider in evaluating the working environment. The factors include space and facilities required for performing the work, superior relationships, equality of treatment at the workplace, communication system at the workplace, conducive working environment, and the procedures to determine and control hazards.

Past studies found that working environment has a significant positive effect on job satisfaction (Mokaya, Musau, Wagoki, \& Karanja, 2013; Pitaloka \& Sofia, 2014; Raziq \& Maulabakhsh, 2015). Lee and Brand (2005) in their research also had showed that job satisfaction was increased because of the conducive working environment. Their study concluded that businesses should realize the importance of having a good working environment to maximize the levels of job satisfaction. Furthermore, Roelofsen (2002) found that the work environment plays an important role in affecting job satisfaction, where the comfortable working conditions minimize employees' complaints and their level of absence. Based on the above discussion, the following hypothesis is proposed:

H4: Work environment has positive effect on job satisfaction.

\section{Methodology}

This study is designed to examine the effects of human resource practices (employee engagement, employee motivation, organizational learning, and work environment) on job 
satisfaction in higher education sector. The population of this study is comprised of administrative and academic staff at public universities in northern Malaysia. Quantitative research approach is considered to be suitable to fulfil the objectives of this study. The data was collected using an online survey from 242 respondents through electronic mail. This method is appropriate to understand how one or multiple factors can influence each other. Structural equation modelling was then employed to analyse the collected data and test the hypotheses which were presented above.

The measurement scales of constructs were adapted from previous studies. Specifically, job satisfaction was measured using five items adapted from Sabri, Ilyas, and Amjad (2011). To measure employee motivation, a nine items scale was adapted from the study of Curtis, Upchurch, and Severt (2009). Moreover, employee engagement was measured using seven items being taken from Schaufeli and Bakker (2003). To measure organizational learning, five items were adapted from Joo and Park (2010). Finally, work environment was measured using six items adapted from the study of McGuire and McLaren (2009). All of the measurement scales were selected because they were reported at high reliability Cronbach's alpha values of more than 0.70 . The items were measured on a five-point Likert scale ranging from 1 "strongly disagree" to 5 "strongly agree". The designed questionnaire was at first sent to three experts from educational sector to validate it and give their opinions.

\section{Analysis of Results}

Out of 870 online surveys being administered to the respondents, only 242 were returned back. The descriptive statistics of results indicated that $65(26.1 \%)$ of the participants are male while $65(73.1 \%)$ are female. The majority of the respondents $(50 \%)$ fall in the age group of 26 to 35 years old, whereas 7 (2.9\%) in the age group of 18 to 25 years. Those whose ages ranged between 36 and 45 years represented $40.5 \%$ of overall response, but 16 $(6.6 \%)$ were in the age category of 46 years and above. On educational qualification, the findings indicated that $36(14.9 \%)$ of the respondents had diploma degree, $79(32.6 \%)$ had undergraduate degree, $125(51.7 \%)$ had postgraduate degree, and only $2(0.8 \%)$ had other professional qualification. Additionally, the results revealed that most of the respondents who participated in the survey had more than five years of working experience at their current institutions.

To check the reliability of measurement items, the Cronbach's alpha was utilized. Overall, the findings supported that the Cronbach's alpha values of all constructs were reasonable ranging from 0.770 to 0.882 ; job satisfaction (0.840), employee engagement $(0.882)$, employee motivation (0.770), work environment (0.837), organizational learning (0.881). Based on these results, it can be concluded that the Cronbach's alpha reliability of all variables is acceptable and more than the minimum cut-off value of 0.70 as suggested by Pallant (2010). The reliability of constructs was also assessed through composite reliability calculations which were done on Microsoft Excel. The results also indicated that the values for all constructs are acceptable. Therefore, the reliability assumptions were achieved.

Furthermore, confirmatory factor analysis (CFA) was performed to confirm the convergent validity of items and deal with Multicollinearity issues. Another purpose for CFA is to ensure 


\section{MInstitute Macrothink $_{\text {Int }}$}

International Journal of Human Resource Studies

ISSN 2162-3058

that each set of items that are supposed to measure a variable are in fact measuring it. As the measurement scales were taken from past studies, CFA instead of exploratory factor analysis (EFA) is then used. The procedure for conducting CFA was done using structural equation modelling (AMOS 18) through the measurement model which is comprised of all items. The findings revealed that the values of factor loadings ranged between 0.53 and 0.90 . Hence, it can be concluded that all items exceeded the minimum recommended value of 0.5 as proposed by Hair el al. (2010).

The next step after conducting CFA on AMOS through the measurement model was to draw the structural model and ensure that it fits the data well. This procedure is very important in order to be able to make conclusions and examine the model. As shown in Figure 1, the results indicate that the structural model achieved adequate fit for the current data as the value of Chi-square is equal to 847.498. To support the Chi-square, other fit indices ( $\mathrm{df}=367$, $\mathrm{GFI}=0.807, \mathrm{AGFI}=0.771, \mathrm{TLI}=0.852, \mathrm{CFI}=867$, and $\mathrm{RMSEA}=0.074$ ) were also used. In general, the structural fits the data well.

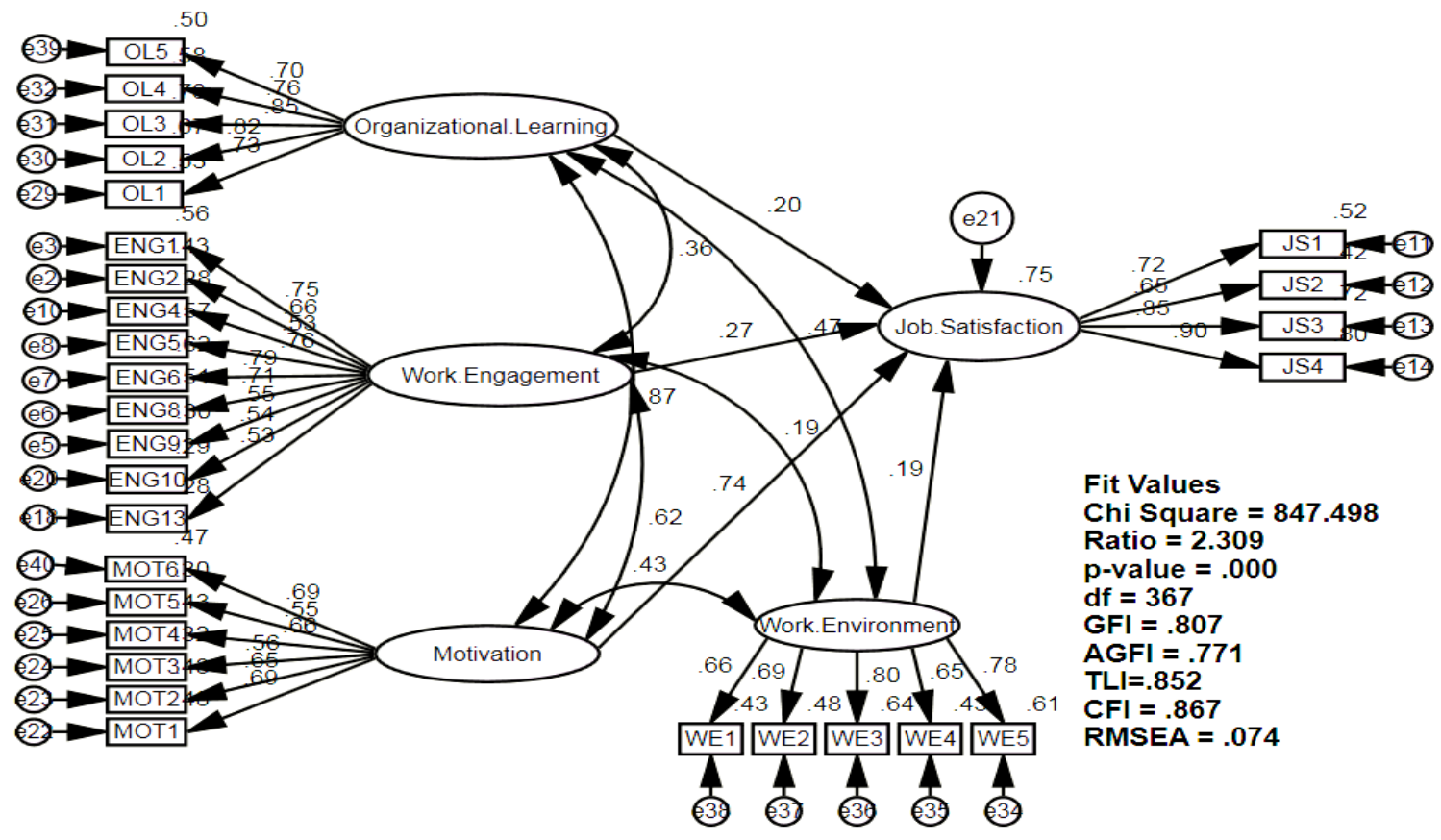

Figure 1. Structural Model

To test the hypotheses, the regression table was extracted from the outputs of structural model. The results presented in Table 1 indicate that employee engagement has significant positive effect on job satisfaction $(\beta=0.267$, t-value $=2.225$, $p<0.05)$, therefore, $\mathrm{H} 1$ is accepted. The findings also revealed that employee motivation has significant positive effect on job satisfaction $(\beta=0.738, \mathrm{t}$-value $=2.543, \mathrm{p}<0.05)$, hence, $\mathrm{H} 2$ is accepted. Furthermore, the effect of organizational learning on job satisfaction is positive and statistically significant ( $\beta$ $=0.202$, $\mathrm{t}$-value $=4.230, \mathrm{p}<0.05)$, thus, $\mathrm{H} 3$ is supported. Finally, the results indicated that work environment has a significant positive effect on job satisfaction $(\beta=0.195$, $t$-value $=$ 3.101, p < 0.05), hence, $\mathrm{H} 4$ is confirmed. Overall, employee engagement, employee motivation, organizational learning, and work environment explain 75 percent of total 
variance in job satisfaction.

Table 1. Results of Hypotheses

$\begin{array}{llllll}\text { Hypothesized Effect } & \begin{array}{l}\text { Std. } \\ \text { Estimate }\end{array} & \text { S.E. } & \text { C.R. } & \text { P } & \text { Support }\end{array}$

H1: Employee engagement has positive $0.267 \quad 0.115 \quad 2.225 \quad 0.026$ Yes effect on job satisfaction.

H2: Employee motivation has positive $0.738 \quad 0.214 \quad 2.543$ *** $\quad$ Yes effect on job satisfaction.

H3: Organizational learning has positive $0.202 \quad 0.067 \quad 4.230$ *** $\quad$ Yes effect on job satisfaction.

H4: Wok environment has positive effect $0.195 \quad 0.050 \quad 3.101 \quad 0.002$ Yes on job satisfaction.

\section{Discussion and Conclusion}

The main purpose of this study was to examine the effects of human resource practices (work engagement, work motivation, organizational learning, and work environment) on job satisfaction. The findings indicated that employee engagement has a significant positive effect on job satisfaction. A greater support was reported in several previous studies (Imam \& Shafique, 2014; Kamalanabhan et al., 2009; Nowack, 2011) which found that employee engagement played an important role in affecting job satisfaction. This means that highly engaged employees tend to exhibit higher degrees of satisfaction in their jobs. The significant result explains the importance of employees' engagement in improving their satisfaction towards the job. Thus, it is suggested that the management in higher educational institutions should work out the necessary control and arrangements for employees to ensure they are doing the right things and provide the adequate facilities as desired. Such activities will enhance the satisfaction of employee by having a sense of achievement and efficient utilization of the time at workplace.

The findings also indicated that employee motivation has a significant positive impact on job satisfaction. The result is in line with a number of previous studies which found a significant relationship between employee motivation and job satisfaction (Hussain et al., 2012; Khalid et al., 2011; Sohail et al., 2014). Ifinedo (2003) also demonstrated that highly motivated employees tend to be satisfied with their jobs and are willing to give high contribution to the organizations in order to achieve the desired outcomes. The significance of employee motivation in affecting job satisfaction indicates that policy makers should put greater emphasis to motivating factors and ensure that the workforce receive fair wages for their efforts and get rewards and job promotions for good achievements. Such activities will inspire employees to be more productive and guide the organization in enhancing its 
competitiveness and survival on the long-term.

This study also indicated that organizational learning has a significant positive effect on job satisfaction and it was supported by several previous studies (Egan et al., 2004; Jolodar \& Jolodar, 2012; Razali et al., 2013; Rose, Kumar, \& Pak, 2005). Rowden and Conine (2005) investigated the effect of organizational learning on job satisfaction and found a significant positive relationship between both variables. Their research outcomes revealed that higher job satisfaction can be attributed to the availability of learning opportunities in the organization. Additionally, Vemić (2007) emphasized on the importance of organizational learning in the development of job satisfaction and employee's performance. The positive effect of organizational learning on job satisfaction urges the management in higher educational institutions to cope with the changes in market environment by designing beneficial programs for increasing the learning opportunities for their employees. It is believed that such learning programs will influence the performance of employees and ultimately can lead to organizational success.

Finally, the results of this study indicated that work environment has a significant positive effect on job satisfaction and it is in line with previous researches (Pitaloka \& Sofia, 2014; Raziq \& Maulabakhsh, 2015; Roelofsen, 2012). According to Jain and Kuar (2014), effective work environment had a positive effect on job satisfaction and satisfied employees ultimately drive organisational growth and economy. Moreover, Widodo (2014) reported that work environment had a significant positive effect on job satisfaction. This means that a good working environment enhances the motivation and satisfaction of employees which is necessary to organizational performance. Therefore, the practical implication from this result is that the management in higher educational institutions should design pleasant working environment for their employees by taking into consideration their welfare facilities and satisfaction.

Similar to any research, this study has some limitations that should be taken into consideration in future research. First, the focus of this study is higher educational institution in northern Malaysia and this may hinder the generalizability of the results to other areas or sectors. Therefore, future researches should test the variables under consideration in this study in different industry and country contexts. Moreover, this study has relied on a survey method for collecting the data from respondents, thus, qualitative research methodologies may yield useful outcomes to further guide policy makers in designing their strategies. Finally, this study examined the direct effects of the stated variables on job satisfaction. Future researches may propose some mediating or moderating variables to clearly understand the key predictors of job satisfaction.

\section{References}

Altindis, S. (2011). Job motivation and organizational commitment among the health professionals: A questionnaire survey. African Journal of Business Management, 5(21), 8601-8609.

Arnold, J. \& Feldman, C. (1986). Organizational behavior. New York: McGraw Hill Book. 


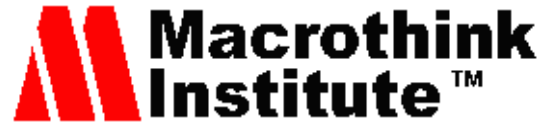

International Journal of Human Resource Studies

ISSN 2162-3058

Arnold, J., \& Silvester, J. (2005). Work psychology: Understanding human behaviour in the workplace. Pearson Education.

Bakker, A. B., \& Demerouti, E. (2008). Towards a model of work engagement. Career Development International, 13(3), 209-223.

Bakotić, D. F., \& Babić, T. (2013). Relationship between working conditions and job satisfaction: The case of Croatian Shipbuilding Company. International Journal of Business and Social Science, 4(2), 206-213.

Buckingham, M., \& Coffman, C. (1999). First, break all the rules: What the worlds greatest managers do differently. Simon and Schuster.

Chang, S. C., \& Lee, M. S. (2007). A study on relationship among leadership, organizational culture, the operation of learning organization and employees' job satisfaction. The learning organization, 14(2), 155-185.

Chiva, R., Alegre, J., \& Lapiedra, R. (2007). Measuring organisational learning capability among the workforce. International Journal of Manpower, 28(3/4), 224-242.

Choe, J. M. (2004). The relationships among management accounting information, organizational learning and production performance. The Journal of Strategic Information Systems, 13(1), 61-85.

Chonko, L. B., Dubinsky, A. J., Jones, E., \& Roberts, J. A. (2003). Organizational and individual learning in the sales force: an agenda for sales research. Journal of Business Research, 56(12), 935-946.

Curtis, C. R., Upchurch, R. S., \& Severt, D. E. (2009). Employee motivation and organizational commitment: a comparison of tipped and nontipped restaurant employees. International Journal of Hospitality \& Tourism Administration, 10(3), 253-269.

Echols, M. E. (2005). Engaging employees to impact performance. Chief Learning Officer, 4(2), 44-48.

Emami, R., Moradi, E., Idrus, D., \& Almutairi, D. O. (2012). Investigating the relationship between organizational learning culture, job satisfaction and turnover intention in it SMEs. International Journal of Innovative Ideas, 12(1), 8-23.

Fleming, J. H., \& Asplund, J. (2007). Human Sigma. New York; Gallup Press.

Goh, S., \& Richards, G. (1997). Benchmarking the learning capability of organizations. European Management Journal, 15(5), 575-583.

Hair, J. F., Jr., Black, W. C., Babin, B. J., Anderson, R. E., \& Tatham, R. L. (2010). Multivariate data analysis (7th edition), Upper Saddle River, N.J: Pearson Prentice Hall.

Harter, J. K., Schmidt, F. L., \& Hayes, T. L. (2002). Business-unit-level relationship between employee satisfaction, employee engagement, and business outcomes: a meta-analysis. Journal of applied psychology, 87(2), 268. 


\section{MInstitute Macrothink $_{\text {Int }}$}

International Journal of Human Resource Studies

ISSN 2162-3058

Hsu, H. Y. (2009). Organizational learning culture's influence on job satisfaction, organizational commitment, and turnover intention among $R \& D$ professionals in Taiwan during an economic downturn (Doctoral dissertation, University of Minnesota).

Hussain, R. I., Usman, S., Sarmad, S. M., \& Haq, I. U. (2012). Effect of work motivation on Job Satisfaction in Telecommunication sector of Pakistan-A case study of Pakistan Telecommunication Company Limited (PTCL). International Journal of Asian Social Science, 2(11), 1925-1933.

Ifinedo, P. (2003). Employee motivation and job satisfaction in Finnish organizations: A Study of employees in the Oulu Region, Finland. (Unpublihd Master Thesis, University of London).

Imam, A., \& Shafique, M. (2014). Impact of employee engagement in retaining employees through mediating effect of job satisfaction and organizational commitment and moderating effect of job stress: A Corporate banking sector study of Pakistan. Journal of Applied Environmental and Biological Sciences, 4(12), 1-15.

Jain, R., \& Kaur, S. (2014). Impact of work environment on job satisfaction. International Journal of Scientific and Research Publications, 4(1), 1-8.

Jolodar, S. Y. E., \& Jolodar, S. R. E. (2012). The Relationship between Organizational Learning Capability and Job Satisfaction. International Journal of Human Resource Studies, 2(1), 15.

Joo, B. K., \& Park, S. (2010). Career satisfaction, organizational commitment, and turnover intention: The effects of goal orientation, organizational learning culture and developmental feedback. Leadership \& Organization Development Journal, 31(6), 482-500.

Kahn, W. A. (1990). Psychological conditions of personal engagement and disengagement at work. Academy of Management Journal, 33(4), 692-724.

Kamalanabhan, T. J., Prakash Sai, L., \& Mayuri, D. (2009). Employee engagement and job satisfaction in the information technology industry. Psychological reports, 105(3), 759-770.

Lane, K. A., Esser, J., Holte, B., \&McCusker, M. A. (2010). A study of nurse faculty job satisfaction in community colleges in Florida. Teaching and Learning in Nursing, 5(1), 16-26.

Lee-Kelley, L., Blackman, D. A., \& Hurst, J. P. (2007). An exploration of the relationship between learning organizations and the retention of knowledge workers. The Learning Organization, 14(3), 204-221.

Leslie, B., Aring, M. K., \& Brand, B. (1998). Informal learning: The new frontier of employee \& organizational development. Economic Development Review, 15(4), 12.

Lo, M. C., \& Ramayah, T. (2011). Mentoring and job satisfaction in Malaysian SMEs. Journal of Management Development, 30(4), 427-440.

Lopez, S. P., Peon, J. M. M., \& Ordas, C. J. V. (2005). Organizational learning as a 


\section{Macrothink}

International Journal of Human Resource Studies ISSN 2162-3058 2016, Vol. 6, No. 1

determining factor in business performance. The Learning Organization, 12(3), 227-245.

Luthans, F. (2005). Organizational behavior. New York: McGraw Hill.

Luthans, K. W., \& Sommer, S. M. (2005). The impact of high performance work on industry-level outcomes. Journal of Managerial Issues, 327-345.

Maduka, C. E., \& Okafor, O. (2014). Effect of motivation on employee productivity: A Study of manufacturing companies in Nnewi. International Journal of Managerial Studies and Research, 2(7), 137-147.

Maharjan, S. (2012). Association between work motivation and job satisfaction of college teachers. Administration and Management Review, 24(2), 45-55.

Marquardt, M. J. (1996). Building the learning organization. New York, NY: McGraw-Hill Companies.

McEwen, D. (2011). Employee engagement: A Systemic approach to high employee engagement. Available at:

http://www.cgnglobal.com/sites/default/files/Employee_Engagement_CGN\%20Global.pdf

McGuire, D., \& McLaren, L. (2009). The impact of physical environment on employee commitment in call centres: The mediating role of employee well-being. Team Performance Management: An International Journal, 15(1/2), 35-48.

Mokaya, S. O., Musau, J. L., Wagoki, J., \& Karanja, K. (2013). Effects of organizational work conditions on employee job satisfaction in the hotel industry in Kenya. International Journal of Arts and Commerce, 2(2), 79-90.

Moradi, E., Almutairi, D. O., Idrus, D., \& Emami, R. (2011). The influence of organizational learning culture on job satisfaction among academic staff. Journal of Global Management, $1-12$.

Naufal, P., Suryaputra, R., \& Sondakh, O. (2012). The effect of work environment and job motivation on job satisfaction and job performance in PT. X, 200-205.

Moradi, E., Almutairi, D. O., Idrus, D., \&Emami, R. (2011). The influence of organizational learning culture on job satisfaction among academic staff. Journal of Global Management, $1-12$.

Nowack, K (2011). Employee engagement, job satisfaction, retention and stress. Retrieved on $28 \quad$ September, 2014 from: https://www.envisialearning.com/system/resources/31/78-abstractFile.pdf?1269662389

Pallant, J. (2010). SPSS: Survival Manual (4th edition), Berkhire: Open University Press.

Peretomode, V. F. (1991). Educational Administration: Applied Concepts and Theoretical Perspective. Lagos: Joja Educational Research and Publishers

Pitaloka, E., \& Sofia, I. P. (2014). The effect of work environment, job satisfaction, 
organization commitment on OCB of internal auditors. International Journal of Business, Economics and Law, 5(2), 10-18.

Razali, M. Z. M., Amira, N. A., \& Shobri, N. D. M. (2013). Learning organization practices and job satisfaction among academicians at public university. International Journal of Social Science and Humanity, 3(6), 518.

Raziq, A., \& Maulabakhsh, R. (2015). Impact of working environment on job satisfaction. Procedia Economics and Finance, 23, 717-725.

Robbins, S. (2001). Managing today. Prentice Hall: New Jersey.

Robbins, S. P. (2003). Organizational behavior. Upper Saddle River, NJ: Prentice Hall.

Roelofsen, P. (2002). The impact of office environments on employee performance: The design of the workplace as a strategy for productivity enhancement. Journal of Facilities Management, 1(3), 247-264.

Roodt, G., Rieger, H. S., \& Sempane, M. E. (2002). Job satisfaction in relation to organisational culture. SA Journal of industrial Psychology, 28(2), 23-30.

Rose, R. C., Kumar, N., \& Pak, O. G. (2011). The effect of organizational learning on organizational commitment, job satisfaction and work performance. Journal of Applied Business Research, 25(6), 55-66.

Rothmann, S. and Storm, K. (2003). Work engagement in the South African Police Service. Available at: http://www.sajip.co.za/index.php/sajip/article/view/925/973.

Rowden, R. W., \& Conine Jr, C. T. (2005). The impact of workplace learning on job satisfaction in small US commercial banks. Journal of workplace Learning, 17(4), 215-230.

Sabri, P. S., Ilyas, M., \& Amjad, Z. (2011). Organizational culture and its impact on the job satisfaction of the University teachers of Lahore. International Journal of Business and Social Science, 2(24), 121-128.

Saleem, R., Mahmood, A., \& Mahmood, A. (2010). Effect of work motivation on job satisfaction in mobile telecommunication service organizations of Pakistan. International Journal of Business and Management, 5(11), 213.

Sanford, B. (2003). Building a Highly Engaged Workforce: How great managers inspire virtuoso performance. Gallup Management Journal.

Schaufeli, W. B., \& Bakker, A. B. (2003). Utrecht work engagement scale: Preliminary manual. Occupational Health Psychology Unit, Utrecht University, Utrecht.

Senge, P. M. (2006). The fifth discipline: The art and practice of the learning organization. Broadway Business. New York: Doubleday.

Shanks, N. H. (2007). Management and motivation. Introduction to Health Care Management, 23. 


\section{Macrothink}

International Journal of Human Resource Studies

ISSN 2162-3058 2016, Vol. 6, No. 1

Shuck, M. B., Rocco, T. S., \& Albornoz, C. A. (2011). Exploring employee engagement from the employee perspective: implications for HRD, Journal of European Industrial Training, $35(4), 300-325$.

Sohail, R. S., Saleem, S., Ansar, S., \& M Azeem, A. (2014). Effect of Work Motivation and Organizational Commitment on Job Satisfaction: (A Case of Education Industry in Pakistan). Global Journal of Management and Business Research, 14(6).

Spector, P. E. (2003). Industrial and organizational psychology - Research and practice (3rd edition). New York: John Wiley \& Sons, Inc.

Spector, P. E. (1997). Job satisfaction: Application, assessment, causes, and consequences. Thousand Oaks, CA, Inc (Vol. 3). Sage Publications.

Storm, K., \& Rothmann, S. (2003). A psychometric analysis of the Utrecht Work Engagement Scale in the South African police service. SA Journal of Industrial Psychology, 29(4), 62-70.

Sundaray, B. K. (2011). Employee engagement: A Driver of organizational effectiveness. European Journal of Business and Management, 3(8), 53-59.

Widodo, D. S. (2014). Influence of leadership and work environment to job satisfaction and impact to employee performance (Study on industrial manufacture in west Java). Journal of Economics and Sustainable Development, 5(26), 62-66.

Vemić, J. (2007). Employee training and development and the learning organization. FACTA UNIVERSITATIS Series: Economics and Organization, 4(2), 209-216.

Yang, B., Lim, T., \& McLean, G. N. (2003). Impacts of organization's learning culture on job satisfaction and organizational commitment: a structural equation modeling approach. Human Resource Development in Asia: National Policy Perspectives, National Institute of Development Administration and Academy of Human Resource Development, Bangkok, 361-9. 


\section{Appendix}

Appendix 1. Measurement Scales of Constructs

\begin{tabular}{|c|c|c|}
\hline Code & Construct/ Item & $\begin{array}{l}\text { Factor } \\
\text { Loading }\end{array}$ \\
\hline & Work Engagement $($ Cronbach's Alpha $=\mathbf{0 . 8 8 2})$ & \\
\hline ENG1 & At this institution, I feel energetic to do my work. & 0.75 \\
\hline ENG2 & At this institution, I feel strong and capable to do my work. & 0.66 \\
\hline ENG4 & I can continue working for very long period at a time. & 0.53 \\
\hline ENG5 & I find the work that I do full of meaning and purpose. & 0.76 \\
\hline ENG6 & I am enthusiastic about my job. & 0.79 \\
\hline ENG8 & I am proud on the work that I do. & 0.71 \\
\hline ENG9 & To me, my job is challenging. & 0.55 \\
\hline ENG10 & Time flies when I'm working. & 0.54 \\
\hline \multirow[t]{2}{*}{ ENG13 } & I have a lot of work to do everyday & 0.53 \\
\hline & Motivation $($ Cronbach's Alpha $=\mathbf{0 . 7 7 0})$ & \\
\hline MOT1 & My institution provides me with a job security. & 0.69 \\
\hline MOT2 & I receive supervisor's help with my personal problems. & 0.65 \\
\hline MOT3 & In my institution, I get good wages. & 0.56 \\
\hline MOT4 & Working in this institution is interesting. & 0.60 \\
\hline MOT5 & $\begin{array}{l}\text { In this institution, I get promotion or career development for } \\
\text { good achievements. }\end{array}$ & 0.55 \\
\hline MOT6 & $\begin{array}{l}\text { The management of the institution show gratitude for a job well } \\
\text { done. }\end{array}$ & 0.69 \\
\hline
\end{tabular}




\begin{tabular}{|c|c|c|}
\hline & Work Environment (Cronbach's Alpha $=\mathbf{0 . 8 3 7})$ & \\
\hline WE1 & I am satisfied with the space allocated for me to do my work. & 0.66 \\
\hline WE2 & My workplace is very clean. & 0.69 \\
\hline WE3 & There is adequate space between me and my nearest colleague. & 0.80 \\
\hline WE4 & My work environment is quiet. & 0.65 \\
\hline \multirow[t]{2}{*}{ WE5 } & $\begin{array}{l}\text { Overall, my work environment is pleasant and visually } \\
\text { appealing. }\end{array}$ & 0.78 \\
\hline & Organizational Learning (Cronbach's Alpha = 0.881) & \\
\hline OL1 & Our institution creates continuous learning opportunities. & 0.73 \\
\hline OL2 & Our institution encourages knowledge sharing among the staff & 0.82 \\
\hline OL3 & $\begin{array}{l}\text { The leader of our institution supports learning at the individual, } \\
\text { team, and organization levels. }\end{array}$ & 0.85 \\
\hline OL4 & $\begin{array}{l}\text { Our institution establishes systems to capture and share } \\
\text { learning. }\end{array}$ & 0.76 \\
\hline \multirow[t]{2}{*}{ OL5 } & $\begin{array}{l}\text { Our institution connects the staff to the environment through } \\
\text { various programs. }\end{array}$ & 0.70 \\
\hline & Job Satisfaction $($ Cronbach's Alpha $=0.840)$ & \\
\hline JS1 & I like doing the things that I do at my workplace. & 0.72 \\
\hline JS2 & I am satisfied with my earning from my current job. & 0.65 \\
\hline JS3 & $\begin{array}{l}\text { I am extremely glad that I chose this institution } \\
\text { to work for, over other institutions. }\end{array}$ & 0.85 \\
\hline JS4 & Overall, I am satisfied with my current job. & 0.90 \\
\hline
\end{tabular}

